\title{
The Effectiveness of Melati Book Program to Improve Healthy Behavior and Reduce Blood Pressure in Hypertensive Patients at Sidorejo Kidul Community Health Center in Salatiga
}

\author{
Ony Suciati'), Didik Gunawan Tamtomo²), Prawito3) \\ 1)Masters Program in Public Health, Universitas Sebelas Maret \\ 2)Faculty of Medicine, Universitas Sebelas Maret \\ 3)Faculty of Social science and Politics, Universitas Sebelas Maret
}

\section{ABSTRACT}

Background: 319 cases of hypertension patients occurred in the community health center in the last 2 years throughout 2019 and 256 cases up to March 2020. Therefore, fighting hypertension was one of the main programs at Sidorejo Kidul Community Health Center. This program was realized by publishing and distributing Melati Book or Books Against Hypertension to hypertension patients. However, the hospital has never conducted a study on whether the distribution of the Melati Book was effective in fighting hypertension in patients in Sidorejo Kidul Community Health Center.

Subjects and Method: The study method was Quasi-experiment. This study used a random-number method to obtain the sample. A sample of 150 hipertensive patients was classified into 2 groups: 75 patients were in the intervention group and 75 other patients were in the control group. The data were analyzed by t-test.

Results: After intervention, mean score of healthy behavior in the intervention group
(Mean= 3.57; $\mathrm{SD}=0.10$ ) was higher than the control group (Mean=0.49; $\mathrm{SD}=0.19)$ and it was statistically significant $(\mathrm{p}<0.001)$. After intervention, mean score of systolic blood pressure in the intervention group (Mean= 32.59; $\mathrm{SD}=1.02)$ was lower than the control group (Mean= -6.83; $\mathrm{SD}=1.02)$ and it was statistically significant $(\mathrm{p}<0.001)$.

Conclusion: Melati book can be used to improve the healthy behavior and reducing blood pressure in hypertensive patients at Sidorejo Kidul Community Health Center in Salatiga.

Keywords: melati book, healthy behavior, decrease in blood pressure

\section{Correspondence:}

Oni Suciati. Masters Program in Public Health, Universitas Sebelas Maret. Jl. Ir. Sutami 36A, Surakarta 57126, Central Java. Email: onysuciati975@gmail.com. Mobile: 081327073562.

\section{Cite this as:}

Suciati O, Tamtomo DG, Prawito (2020). The Effectiveness of Melati Book Program to Improve Healthy Behavior and Reduce Blood Pressure in Hypertensive Patients at Sidorejo Kidul Community Health Center in Salatiga. J Health Promote Behav. 05(04): 264-271. https://doi.org/10.26911/thejhpb.2020.05.04.04. (c) (i) (-) Jo Journal of Health Promotion and Behavioris licensed under a Creative Commons

BACKGROUND

Hypertension or high blood pressure is a chronic disease that occurs due to excessive and inconsistent blood pressure in the arteries, associated with increasing systemic arterial pressure, both diastolic and systolic, or even both continuously (Sutanto, 2010).
Hypertension is related to healthy living behavior. It is a behavior related to a person's efforts to maintain and improve his/her health status (Notoadmodjo, 2014). Becker (1979), in Notoadmodjo (2014), classified healthy living behaviors into several parts: doing regular exercise, having non-smoking habits, eating a balanced diet, consuming no drugs and alcohol, control- 
Suciati et al./ The Effectiveness of Melati Book Program to Improve Healthy Behavior

ling stress, getting enough rest, and having a positive lifestyle for health.

According to the results of preliminary observations conducted by researchers at Sidorejo Kidul Community Health Center, 319 cases of hypertension sufferers occurred in the community health center in the last 2 years throughout 2019 and 256 cases up to March 2020. Therefore, fighting hypertension was one of the main programs at Sidorejo Kidul Community Health Center. This program was realized by publishing and distributing Melati Book or Books Against Hypertension to hypertension patients.

The distribution of this book was expected to provide information or knowledge about hypertension problems to patients, thus motivating patients to change their lifestyle to be healthier; this book was also expected to control the development of patient blood pressure. However, the effectiveness of distributing the Melati Book to fight hypertension in patients at Sidorejo Kidul Community Health Center has never been conducted.

It encouraged the researchers to conduct an in-depth study on the effectiveness of distributing Melati Book to improve healthy behavior and reduce blood pressure in hypertensive patients.

\section{SUBJECTS AND METHOD}

\section{Design of the study}

This was a quasi-experiment.

\section{Population and Sample}

The population of this study was all hypertensive patients in Sidorejo Kidul Community Health Center, Salatiga. This study used a random sampling technique to obtain the sample.

The sample of this study was 150 study subjects: 75 subjects in the control group and 75 other subjects in the intervention group.

\section{Study Variables}

The dependent variables were blood pressure and healthy behavior. The independent variable was the Melati book program.

\section{Operational definition of variables}

Melati Book or Book Against Hypertension was a book that contained education on healthy living behaviors and the results of measuring blood pressure for monitoring patient blood pressure. This book was distributed to hypertensive patients at Sidorejo Kidul Community Health Center as one of the main programs to fight hypertension Sidorejo Kidul Community Health Center.

Healthy living behavior was patient behavior related to efforts to fight hypertension such as checking-up for blood pressure, not smoking, having a low-fat diet, doing regular exercise, consuming fruits and vegetables, and consuming medication regularly (Yes=1, No=0 ).

Decrease in blood pressure was a medical condition where there was a decrease in blood pressure in hypertensive patients under $140 / 90 \mathrm{mmHg}$ to be normal-high, normal, or optimal (NormalHigh, Normal, Optimal).

\section{Instruments of the study}

This study used a questionnaire, Melati Book, and Blood Pressure Monitor.

\section{Data analysis}

This study used bivariate analysis with the t-test. It compared the results of the sample that was given the intervention: Melati book and non-Melati book.

\section{Research ethics}

This study was carried out after obtaining permission from the Ethics Committee of Moewardi Hospital, Solo City, with EC Number:1.240/XI/HREC/2020.

\section{RESULTS}

There were 15 subjects of the study. Based on the results of the study, most of the 
Suciati et al./ The Effectiveness of Melati Book Program to Improve Healthy Behavior

study subjects in the intervention group aged 41-60 years (44\%) and most of the study subjects in the control group aged 4160 years $(54.70 \%)$. Based on the education category, most of the study subjects had senior high school education, both in the intervention group (69.30\%) and in the control group (50.70\%). According to the sex category, most of the study subjects were male, both in the intervention group (53.30\%) and in the control group (56\%).

Table 1. Sample Characteristics

\begin{tabular}{llcccc}
\hline \multirow{2}{*}{ Variables } & \multicolumn{2}{c}{ Characteristics } & \multicolumn{2}{c}{ Intervention Group } & \multicolumn{2}{c}{ Control Group } \\
\cline { 2 - 5 } & & $\mathbf{n}$ & $\mathbf{\%}$ & $\mathbf{n}$ & $\mathbf{\%}$ \\
\hline Age (year) & $18-40$ & 32 & 42.70 & 22 & 29.30 \\
& $41-60$ & 33 & 44.00 & 41 & 54.70 \\
Education & $>60$ & 10 & 13.30 & 12 & 16.00 \\
& Primary School & 11 & 14.70 & 10 & 13.30 \\
& Junior High School & 8 & 10.70 & 18 & 24.00 \\
& Senior High School & 52 & 69.30 & 38 & 50.70 \\
& Diploma & 1 & 1.30 & 3 & 4.00 \\
Sex & Bachelor & 3 & 4.00 & 6 & 8.00 \\
Systemic blood & Male & 40 & 53.30 & 42 & 56.00 \\
pressure & Female & 35 & 46.70 & 33 & 44.00 \\
& Normal & 53 & 70.70 & 8 & 10.70 \\
\multirow{5}{*}{ Systemic blood } & Normal High & 7 & 9.30 & 14 & 18.70 \\
pressure & Stage 1 Hypertension & 12 & 16.00 & 32 & 42.70 \\
& Stage 2 Hypertension & 3 & 4.00 & 21 & 28.00 \\
& Normal & 60 & 80.00 & 18 & 24.00 \\
& Normal High & 1 & 1.30 & 5 & 6.70 \\
& Stage 1 Hypertension & 14 & 18.70 & 52 & 69.30 \\
\hline
\end{tabular}

To examine the difference in the mean of healthy behavior between the intervention group and the control group before-after intervening and the difference

Table 2. The results of the t-test on the difference in the mean of healthy behavior

\begin{tabular}{|c|c|c|c|}
\hline Healthy Behavior & Mean & SD & $\mathbf{p}$ \\
\hline \multicolumn{4}{|l|}{ Pre-intervention } \\
\hline Intervention & 1.89 & 0.16 & $<0.001$ \\
\hline Control & 3.21 & 0.17 & \\
\hline \multicolumn{4}{|l|}{ Post-intervention } \\
\hline Intervention & 5.46 & 0.18 & $<0.001$ \\
\hline Control & 3.70 & 0.13 & \\
\hline \multicolumn{4}{|l|}{ Post - pre-intervention } \\
\hline Intervention & $3 \cdot 57$ & 0.10 & $<0.001$ \\
\hline Control & 0.49 & 0.19 & \\
\hline
\end{tabular}


Suciati et al./ The Effectiveness of Melati Book Program to Improve Healthy Behavior

difference in the mean before intervening occurred due to the quasi-experimental study design. It made the two groups not comparable at baseline. Therefore, the effectiveness of the intervention (Melati book program) was determined by comparing the difference in healthy behavior before intervening. The difference in

Table 3. The results of the t-test on the difference in the mean of systemic blood pressure

\begin{tabular}{lccc}
\hline \multicolumn{1}{c}{ Systemic Blood Pressure } & Mean & SD & P \\
\hline Pre-intervention & & & \\
Intervention & 161.10 & 1.10 & $<0.001$ \\
Control & 154.71 & 1.04 & \\
Post-intervention & & & $<0.001$ \\
Intervention & 128.51 & 1.22 & \\
Control & 147.88 & 1.67 & $<0.001$ \\
Post - pre-intervention & & & \\
Intervention & -32.59 & 1.02 & \\
Control & -6.83 & 1.02 & \\
\hline
\end{tabular}

Table 3 shows that the systolic blood pressure before intervening between the intervention group and the control group differed significantly $(\mathrm{p}<0.001)$. The difference in the mean before intervening occurred due to the quasi-experimental study design. It made the two groups not comparable at baseline. Therefore, the effectiveness of the intervention (Melati's book program) was determined by com- healthy behavior before-after intervening in the intervention group (Mean= 3.57; $\mathrm{SD}=$ o.10) was greater than the control group (Mean= 0.49; $\mathrm{SD}=0.19$ ); it was statistically significant $(\mathrm{p}<0.001)$. As a result, the Melati book program was effective in improving the healthy behavior in adults with hypertension.

Table 4. The results of the t-test on the difference in the mean of diastolic blood pressure

\begin{tabular}{lccc}
\hline \multicolumn{1}{c}{ Diastolic Blood Pressure } & Mean & SD & P \\
\hline Pre-intervention & & & \\
Intervention & 97.69 & 0.50 & $<0.001$ \\
Control & 93.32 & 0.47 & \\
Post-intervention & 83.38 & 0.48 & $<0.001$ \\
Intervention & 88.96 & 0.48 & \\
Control & & & $<0.001$ \\
Post - pre-intervention & -14.31 & 0.52 & \\
Intervention & -4.36 & 0.49 & \\
Control & &
\end{tabular}

Table 4 shows that the diastolic blood pressure before intervening between the intervention group and the control group paring the difference in the systolic blood pressure before-after intervening. The difference in the systolic blood pressure before-after intervening in the intervention group (Mean $=-32.59 ; \quad \mathrm{SD}=1.02)$ was greater than the control group (Mean= 6.83; $\mathrm{SD}=1.02)$; it was statistically significant $(\mathrm{p}<0.001)$. As a result, the Melati book program was effective in reducing systolic blood pressure in adults with hypertension. differed significantly $(\mathrm{p}<0.001)$. The difference in the mean before intervening occurred due to the quasi-experimental 
study design. It made the two groups not comparable at baseline. Therefore, the effectiveness of the intervention (Melati's book program) was determined by comparing the difference in the diastolic blood pressure before-after intervening. The difference in the diastolic blood pressure before-after intervening in the intervention group (Mean $=-14.31 ; \mathrm{SD}=0.52)$ was greater than the control group (Mean= -4.36 ; $\mathrm{SD}=$ 0.49); it was statistically significant ( $p$ $<0.001)$. As a result, the Melati book program was effective in reducing diastolic blood pressure in adults with hypertension.

\section{DISCUSSION}

This study showed that the Melati book program was effective in improving healthy behavior in adults with hypertension. After intervening in the Melati book program, the increase in healthy behavior in the intervention group (Mean=3.57; $\mathrm{SD}=0.10$ ) was greater than the control group (Mean $=0.49$; $\mathrm{SD}=0.19)$; it was statistically significant $(\mathrm{p}<0.001)$

The results showed that the Melati book program was effective in reducing systolic blood pressure in adults with hypertension. After intervening in the Melati book program, the decrease in systolic blood pressure in the intervention group (Mean= -32.59; $\mathrm{SD}=1.02$ ) was greater than the control group (Mean=-6.83; $\mathrm{SD}=1.02)$; it was statistically significant $(\mathrm{p}<0.001)$.

This study showed that the Melati book program was effective in reducing diastolic blood pressure in adults with hypertension. After intervening in the Melati book program, the decrease in diastolic blood pressure in the intervention group (Mean=-14.31; $\mathrm{SD}=0.52)$ was greater than the control group (Mean=-4.36; $\mathrm{SD}=$ 0.49); it was statistically significant (p $<0.001)$.
Based on the results of this study, the behavioral theory by Bloom (1908) could be used as a theoretical basis in improving healthy behavior and reducing blood pressure in hypertensive patients at Sidorejo Kidul Community Health Center, Salatiga. Providing education to hypertensive patients was by distributing Melati Book contained problems related to hypertension, including what was hypertension, risk factors for hypertension, signs, and symptoms, etc., and the attachment contained blood pressure table sheet. It would be written by the officer. Each patient had a blood pressure check-up. It was the right step to increase patient knowledge, thus changing the patient's life behavior to be healthier and reducing patient's blood pressure.

\section{AUTHOR CONTRIBUTION}

Ony Suciati collected the data, wrote the manuscript. Didik Gunawan Tamtomo and Bhisma Murti did data interpretation.

\section{CONFLICT OF INTEREST}

This study was conducted without any commercial or financial relationship that could be interpreted as a potential conflict of interest.

\section{FUNDING AND SPONSORSHIP}

This study did not use any sponsorship.

\section{ACKNOWLEDGEMENT}

The validity and authenticity of this study have been approved based on its innovation by the authors, supervisors, and agencies in its implementation and arrangement.

\section{REFERENCE}

Adib M (2009). Cara mudah memahami dan menghindari hipertensi, jantung dan stroke. Dianloka Pustaka: Yogyakarta. 
Suciati et al./ The Effectiveness of Melati Book Program to Improve Healthy Behavior

Agrina R, Hairitama R (2011). Kepatuhan lansia penderita hipertensi dalam pemenuhan diet hipertensi. Jurnal UNRI. 6(1): $46-53$.

Amir S (2012). Tekanan darah tinggi: Mengapa terjadi, bagaimana mengatasinya. Arcan. Jakarta.

Badan Penelitian dan Pengembangan Kesehatan (LPB). 2019. Laporan Provinsi Jawa Tengah Riskedas 2018. Badan Penelitian dan Pengembangan Kesehatan (LPB). Jakarta.

Bhandari B, Bhattarai M. Bhandar N. Jha. (2012). Awareness of disease and selfcare among hypertensive patients attending Tribhuvan University teaching Hospital, Kathmandu, Nepal. J Nobel Med Col. 1(2): 29-35. https://doi.org/10.3126/jonmc.v1i2.7296.

Darussalam M, Warseno A (2017). Faktor yang berhubungan dengan pasien hipertensi tidak terkontrol di puskesmas. Jurnal Keperawatan Klinis dan Komunitas (Clinical and Community Nursing Journal). 1(2): 72-80. https://jurnal.ugm.ac.id/jkkk/article/view/ 49111.

Departeman Kesehatan RI (2015). Profil Kesehatan Indonesia Tahun 2015. Kementrian Kesehatan RI. Jakarta.

Departemen Kesehatan RI (2002). Panduan Manajeman PHBS Menuju Kabupaten/Kota Sehat. Departemen Kesehatan. Jakarta.

Departemen Kesehatan RI (2006). Pharmaceutical care untuk penyakit hipertensi. Direktorat Bina Farmasi Komunitas dan Klinik Ditjen Bina Farmasi dan Alat Kesehatan. Jakarta.

Dinas Kesehatan Jawa Tengah (2017). Profil Kesehatan Provinsi Jawa Tengah Tahun 2017. Dinas Kesehatan Provinsi Jawa Tengah. Jakarta.

Hanata R (2010). Pola Hidup Sehat Untuk Lansia. CV. Toga Putra. Jakarta.
Hardianti, Amirudin, Masni (2016). Kepatuhan minum obat terhadap status hipertensi di wilayah kerja puskesmas Bajoe Kabupaten Bone Tahun 2016. JST Kesehatan. 6(4): $375-380$

Hardiyanti, Amirudin, Masni (2016). Kepatuhan minum obat terhadap status hipertensi di wilayah kerja Puskesmas Bajoe Kabupaten Bone Tahun 2016. JST Kesehatan. 6(4): $375-380$.

Harwati, Sartika W (2015). Terkontrolnya tekanan darah penderita hipertensi berdasarkan pola diet dan kebiasaan olahraga dipadang tahun 2011. Jurnal Kesehatan Masyarakat. 8(1): 8-14.

Hendriyani, Pertiwi, Mintarsih (2014). Perilaku pemilihan makanan tinggi natrium berpengaruh terhadap asupan natrium penderita hipertensi di Kota Semarang. Gizi Indon. 37(1): 4150.

Hulaima IS (2017). Faktor-faktor yang berhubungan dengan kontrol tekanan darah pada pasien hipertensi di Puskesmas Kedaton Kota Bandar Lampung. Retrieved from https://www.unila/ac.id.

Igam M, Suniyadewi NW, Mudia N (2017). Hubungan dukungan keluarga dengan pola hidup sehat hipertensi pada keluarga. Bali Medical Journal. 4(2): 1-17.

Kemenkes RI (2019). Hari hipertensi dunia 2019: "Know Your Number, Kendalikan Tekanan Darahmu dengan CERDIK". http://p2ptm.kemkes.go.id.

Kienreich, Katharina (2013). Vitamin D, arterial hipertention \& cerebrovascular desease. Indian J Med Res. 137 (4): 669-679.

Kosasih, Hassan I (2013). Patofisiologi klinik. Binarupa Aksara Publisher. Jakarta. 
Suciati et al./ The Effectiveness of Melati Book Program to Improve Healthy Behavior

Osterberg L, Blaschke T (2005). Adherence to Medication. N Engl J Med. 353(5): 487-97. https://doi.org/10.1056/nejmrao50100.

Perdana (2018). Hubungan persepsi tentang hipertensi dengan kepatuhan meminum obat pada pasien hipertensi di poliklinik penyakit dalam RSUD Wates Yogyakarta. Retrieved from https://www.ums.ac.id.

Perhimpunan Dokter Spesialis Kardiovaskular Indonesia (PERKI) (2015). Pedoman tatalaksana hipertensi pada penyakit kardiovaskular. Pengurus Pusat Perhimpunan Dokter Spesialis Kardiovaskular Indonesia (PP PERKI). Jakarta.

Pujiyanto (2008). Faktor Sosio Ekonomi yang Mempengaruhi Kepatuhan Minum Obat Antihipertensi. Kemas, JKMN. 3(3): 139-144.

Purwanto H (2006). Pengantar Perilaku Manusia Untuk Keperawatan. EGC. Jakarta.

Puskesmas Sidorejo Kidul (2019). Buku Melati "Melawan Hipertensi”. Puskesmas Sidorejo Kidul. Salatiga.

Puspita, Aisyah, Sutoyo (2012). Sikap terhadap kepatuhan diit hipertensi dengan tekanan darah pada penderita hipertensi di wilayah kerja Puskesmas Doro II Kabupaten Pekalongan. Jurnal Keperawatan. 5(1): $1-13$.

Ramayulis, R. 2013. Menu dan Resep untuk Penderita Hipertensi. Penebar Plus. Jakarta.

Sari (2015). Gambaran kontrol tekanan darah pada pasien hipertensi di Puskesmas Kasihan 1 Bantul Yogyakarta. Retrieved from https://www.umy.ac.id.

Setyawan, Ismahmudhi (2018). Promosi kesehatan sebagai usaha menurunkan tekanan darah penderita hipertensi. Jurnal Abdimas. 1(2): 119-124.
Smantummkul C (2014). Tingkat kepatuhan penggunaan obat antihipertensi pada pasien hipertensi di instalasi rawat jalan rumah sakit $\mathrm{X}$ Pada Tahun 2014. Retrieved from https://www.ums.ac.id.

Smeltzer, Bare. 2012. Keperawatan Medikal Bedah Brunner \& Suddarth. EGC. Jakarta.

Suharjana (2012). Kebiasaan berperilaku hidup sehat dan nilai-nilai pendidikan karakter. Jurnal Pendidikan Karakter. 2(2): 189-201.

Sunarti, Sunarno, Alvio (2015). Upaya penderita hipertensi untuk mempertahankan pola hidup sehat (Hypertension patients efforts to maintain healthy lifestyles). Jurnal Ners dan Kebidanan. 2(2): 122-129.

Supramono dan Sugiarto. 2010. Statistika. Yogyakarta: Andi Offset.

Susanto dan Alfian R. 2015. Perbaikan Perilaku Dan Tekanan Darah Pasien Hipertensi di RSUD Dr. H. Moch. Ansari Saleh Banjarmasin Setelah Pemberian Leaflet Edukasi Hipertensi dan Terapinya. Jurnal Ilmiah Manuntung. 1(2): 140-144.

Susiati, Hidayati, Yuniarti (2016). Gambaran pengetahuan dan sikap klien tentang cara perawatan hipertensi. Jurnal Care. 4(3): 105-110.

Sutanto (2010). Cekal (cegah \& tangkal) Penyakit Modern. ANDI. Yogyakarta.

Utami P (2009). Solusi Sehat Mengatasi Hipertensi. Jakarta: AgroMedia.

Wati S (2018). Hubungan tingkat pengetahuan dengan perilaku diet pada pasien hipertensi primer di Wilayah Kerja Puskesmas Jenggawah Kabupaten Jember. https://repository.unej.ac.id.

World Health Organization (2013). A gobal brief on hypertension: Silent killer. 
Suciati et al./ The Effectiveness of Melati Book Program to Improve Healthy Behavior

Global Public Health Crisis. World Health Organization. Switzerland.

Yiannakopoulou EC, Papadopulos JS, Cokkinos DV, Mountokalakis TD (2005).

Adherence to antihypertensive treat- ment: A critical factor for blood pressure control. Eur $\mathrm{J}$ Cardiovasc Prev Rehabil. 12(3): 243-9. https://doi.org/10.1097/00149831-200506o00-00010. 